\title{
ANALISIS GAMBAR BENTUK BUNGA ANGGREK DENGAN TEKNIK POINTILIS BERWARNA DI SMP AL-FITYAN SCHOOL MEDAN
}

\author{
Nurlinda Hanum Siregar ${ }^{1 *}$, Adek Cerah Kurnia Azis ${ }^{2 *}$, Mesra $^{3 *}$ Tetty Mirwa $^{4 *}$ \\ Program Studi Pendidikan Seni Rupa Jurusan Seni Rupa Fakultas Bahasa dan Seni \\ Universitas Negeri Medan \\ Jl. Willem Iskandar Pasar V Medan Estate, Kec, Percut Sei Tuan, Kab. Deli Serdang, Kode Pos 20371 \\ Sumatera Utara. Indonesia \\ Email: nurlindahanum09@gmail.com
}

\begin{abstract}
Abstrak
Penelitian inibertujuan untuk mengetahui hasil karya sis wa dalam membuat gambar bentuk Bunga Anggrek dengan teknik pointilis berwarna karya sis wa kelas VIII SMP Al-Fityan School Medan. Penelitian ini termasuk pada jenis penelitian kualitatif. Populasi yang terdapat dalam penelitian ini sebany ak 21 karya gambar bentuk Bunga Anggrek sehingga s ampel yang ditetapkan dalam penelitian ini terdiri dari 5 karya gambarbentuk Bunga Anggrek meng gunakan teknik Purvosive Sampling atau pengambilan sampel dengan pertimbangan tertentu yang dipandang dapat memberikan data secara maksimal. Penilaian dalam penelitian ini mengacu kepada nilai KKM 75 pada mata pelajaran seni budaya. Maka penilaian dalam penelitian menunjukkan bahwa penerapan unsur ggelap-terang 89 , bentuk 87 , ruang 86 , pointilis 88 , kemiripan bentuk 88, tekstur 87 . Maka dari 6 indikator penilaian tersebut unsur yang paling unggul dari 6 indikator y aitu pada uns ur gelap-terang yang menimbulkan kemiripan bentuk. Sedangkan penilaian unsur y ang paling terendah berada pada unsur ruang, dengan penerapan ruang masih kurang menunjukkan keteraturan. Penilaian secara keseluruhan pada unsur pointilis, bentuk, ruang, gelap-terang, kemiripan bentuk, dan tekstur mencapai nilai rata-rata 87 dan termasuk dalam kategori baik, serta pada penerapan gelap-terang mencapai nilai rata-rata 87 dan termasuk dalamkategori baik, maka dari 5 karya gambarbentuk Bunga Anggrek yang mencapai nilai KKM sebanyak 5 karya atau $100 \%$ dari 5 karya gambar bentuk Bunga Anggrek sudah mencapai nilai KKM.
\end{abstract}

Kata Kunci: analis is gambar bentuk, teknik pointilis.

\begin{abstract}
This research aims to determine the work of students in creating drawings of the form of orchid flowers with pointilis techniques written by grade VIII students SMP Al-Fityan School Medan. This research is included in qualitative research. The population contained in this study as much as 21 drawings of the form oforchidflowers so that the samples set in this study consisted of 5 works of drawings of orchid flowers using Purvosive Sampling technique or sampling with Certain considerations that are deemed able to providemaximum data. The assessment in this study refers to the value of 75 in the cultural arts subjects. Then the assessment in the study showed that the application of the elements of the 89-bright ggelap, form 87, Room 86, Pointilis 88, similarity form 88, texture 87. Thus, from the 6 indicators the assessment is the most superior of the 6 indicators that are in the dark-light elements that cause similarities in shape. While the lowest valuation of the element is on the element of space, with the implementation of space still lacking the regularity. The overall assessment of Pointilis, form, space, dark-light, resemblance to shape, and texture reaches a flat-rata87value and belongs to a good category, as well as on the application ofdark-light reaching an average value of 87 and included in Good category, then of 5 works images of orchid form that reaches the value of the KKM as much as 5 works or $100 \%$ of 5 works images of the shape of the orchid has reached the value of the KKM.
\end{abstract}

Keywords: form image analysis, pointilis techniques.

\section{PENDAHULUAN}

Pendidikan seni budaya khususnya dalam Mata Pelajaran Seni Rupa di tingkat pendidikan Sekolah Lanjutan Tingkat Pertama (SLTP) merupakan salah satu Mata Pelajaran yang masih perlu dikembangkan. Mata pelajaran ini memiliki banyaksekalicabangnya, sehingga suatu sekolah tidak mungkin menerapkan semua yang terkandung didalamnya. Pelajaran Seni 
Rupa merupakan pelajaran inti dalam kurikulum SLTP, di mana pada pembelajaran ini siswa diperkenalkan berbagai macamteknik, alat, dan bahan untuk dapat menghasilkan sebuah karya seni rupa. Peran guru sangat penting dalamproses Pembelajaran Seni Rupa.

Proses belajar tersebut tidak lepas dengan apa yang disebut dengan Literasi, dimana konsep literasi dipahami lebih dari sekedar membaca dan menulis, namun mencakup keterampilan berfikir menggunakan sumber-sumber pengetahuan dalam bentuk cetak digital, auditori, dan visual. Visual inilah yang erat kaitanny a dengan Pembelajaran Seni Rupa, (Harahap, M. H., Faisal, F., Hasibuan, N. I., Nugrahaningsih, R. H. D., \& Azis, A. C. K., 2017: 116).

Proses pembelajaran seperti ini, dapat menyalurkan bakat, serta mengembangkan potensi yang dimiliki oleh siswa. Seorang siswa dalam mempelajari mata pelajaran seni rupa memiliki kemampuan dan keahlian yang berbeda-beda pada masing-masing cabang seni rupa yang ada di dalam pembelajaran seni rupa itu sendiri, seperti Seni Patung, Seni Lukis, Grafis, Gambar Ilustrasi, Gambar Sketsa, Gambar Bentuk, dan cabang seni rupa lainnya.

Kegiatan menggambar pada materi Gambar Bentuk yaitu meniru langsung benda-benda yang ada dihadapan peserta didik, baik benda mati maupun benda hidup, tujuannya untuk mencapai suatu ketepatan dalam menggambar sebuah bentuk.

Pelajaran gambar bentuk sangat membantu daya kreativitas peserta didik dan membangkitkan keinginan melihat dan meniru sebuah benda. Gambar benda yang dibuat pun bervariasi, seperti menggambar bunga, buah-buahan, bola, kubus, balok, dan lain sebagainya. Selama melakukan observasi, wawancara dengan guru, dan pengamatan aktivitas sis wa SMP Al Fityan School Medan, didapatkan data, informasi, dan catatan lapangan bahwa, siswa memperoleh materi pembelajaran seni rupa yang difokuskan pada materi gambar bentuk, pada materi ini diterapkan pembuatan gambar dengan objek Bunga Anggrek, guru mengintrusikan pengerjaan tugas pada materi ini dengan teknik pointilis berwarna. Hasil penilaian karya sis wa pada materi ini, dalam membuat karya gambar bentuk teknik arsir jika dilihat dari prinsipprinsip seni rupa, pada siswa kelas VIIIA belum memenuhi KKM (Kriteria ketuntas an minimal), yakni dengan niilai rata-rata 70 masih kurang dibawah nilai padahal nilai KKM 75 hal ini menunjukkan bahwa
Gorga : Jurnal Seni Rupa

Volume 09 Nomor 01 Januari-Juni 2020

p-ISSN: 2301-5942 | e-ISSN: 2580-2380

hampir setengah dari siswa di kelas ini tidak memenuhi KKM (Kriteria Ketuntas an Minimal).

\section{KAJIAN TEORI}

\section{Analisis}

MenurutFurchan dalam buku Pengantar Penelitian

Dalam Pendidikan (2011:513) mengatakan bahwa "Langkah pertama bagi peneliti dalam menganalis is data yang telah dikumpulkan adalah melihat kembali usulan penelitian guna memeriksa rencana penyajian data dan pelaksanaan analisis-statistik yang telah ditetapkan semula. Sesudah hal ini dilakukan, peneliti kemudian mengembangkan strategipenyusunan data mentah dan melaksanakan penghitungan yang diperlukan. Untuk mencapai ketepatan dan untuk menghemat waktu dan tenaga, sebagian besar peneliti memilih untuk memanfaatkan fasilitas alat hitung elektronik bagi analis is data mereka.

\section{Gambar Bentuk}

Menggambar bentuk menjadi landasan dalam menampilkan bentuk-bentuk. Menurut Mesra dalam buku Menggambar Bentuk (2014:9) Menggambar bentuk adalah "Suatu kegiatan memindahkan objek modelyang dilihat langsung, ke atas bidang gambar dengan lebih mengutamakan kemiripan terhadap model tersebut. Contoh sederhana dalam penggambaran bola”.

\section{Bunga}

Menurut Tjitrosoepomo dalam buku Morfologi Tumbuhan (2001:123) bunga adalah kuncup bunga (alabastrum atau gemma florifera), ada pula yang hanya merupakan cabang baru, ada pula yang menjadi cabang baru dengan bunga.

\section{1). Pengertian Anggrek}

Dalam jurnal Wukansari(2016:9) anggrek merupakan salah satu tanaman hias yang banyak penggemarnya bunga beragam, baik warna, motif, dan ukurannya.

\section{2) Jenis-jenis Anggrek}

Hal ini juga diperkuat dalam jurnal TTG Budidaya Pertanian (2017:1) yang menyatakan bahwa: Jenis anggrek yang terdapat diindonesia termasuk jenis y ang indah antara lain: Vanda tricolor terdapat dijawa barat dan kaliurang, Vanda hookeriana, berwarna ungu bwrbintik-bintik berasal dari sumatera, anggrek larat/ dendrobium phalaenopis, anggrek bulan/ phalaenopis amabilis, ang grek appel blossom, anggek paphiopedilun praestans yang berasal dari irian jaya serta anggrek paphiopedilun glaucophyllum yang berasal dari jawa tengah. 


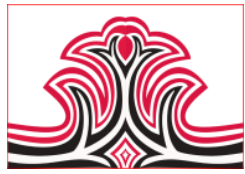

3. Teknik Menggambar Bunga

Menurut Simatupang dalambuku Modul SeniBudaya (2013:37) Setiap orang memiliki karakter yang berbeda dalam menggambar bentuk. Teknik-teknik yang bis a digunakan dalammenggmbar bentuk, antara lain sebagai berikut.

\section{(1). Tek nik pointilis}

Dalam jurnal Wijaya (2010: 256) yang menyatakan bahwa: Teknik Pointilis adalah cara atau teknik menggambar atau melukis dengan menggunakan titiktitik hingga membentuk suatu objek.

\section{Warna}

\section{1) Pengertian Warna}

Nugroho dalam buku Pengenalan Teori Warna (2008:1) menjelaskan warna adalah suatu hal yang sangat penting dalammenentukan respons dari orang lain. Warna adalah hal pertama yang dlihat oleh seseorang. Setiap warna memberikan kesan dan identitas tertentu, walaupun hal ini tergantung pada latar belakang pengamatannya juga.

\section{2) Prinsip-Prinsip Seni Rupa dalam Menggambar} Mesra dalam buku Menggambar Bentuk (2013: 21) menjelaskan Komposisi dalam menggambar merupakan suatu susunan dari beberapa unsur secara seimbang dan serasiatau harmonis, komposisi tersebut terdiri dari beberapa indikator yaitu: kesatuan, keseimbangan, irama, proporsi, keselarasan, dan penekanan.

\section{Unsur-Unsur Seni Rupa}

Unsur-unsur rupa juga disebut unsur-unsur visual (visual elements), unsur-unsur formal atau unsur-unsur desain. Unsur-unsur rupa ialah garis (line), raut atau bangun (shape), warna (colour), gelap terang atau nada (light-dark, tone), tekstur atau barik (texture), dan ruang (space), Sunaryo, (2002: 6).

\section{METODOLOGI PENELITIAN}

Penelitian dilakukan disekolah SMP AlFityan School Medan, yang beralamat Jl. Keluarga, Asam Kumbang, Medan Selay ang, KotaMedan, Sumatera Utara, kode pos 20241.

Metode yang digunakan dalam penelitian ini adalah menggunakan metode kualitatif. Menurut Sugiono Dalam Buku Statistika Untuk Penelitian (2016:15) Metodepenelitian kualitatif adalah metode penelitian yang berlandaskan pada filsafat postpositivisme, digunakan untuk meneliti pada kondisi obyek yang alamiah, (sebagai lawannya adalah eksperimen) dimana peneliti adalah sebagai instrumen kunci,
Gorga : Jurnal Seni Rupa

Volume 09 Nomor 01 Januari-Juni 2020

p-ISSN: 2301-5942 | e-ISSN: 2580-2380

pengambilan sampel sumber data dilakukan secara purposive dan snowbaal, teknik pengumpulan dengan trianggulasi (gabungan), analisis data bersifat induktif/ kualitatif, data hasil penelitian kualitatif lebih menekankan makna dari pada generalisasi.

\section{HASIL DAN PEMBAHASAN \\ 1.Hasil}

Dalam penelitian ini, peneliti menganalisis gambar bunga ang grek dengan teknik pointilis berwarnakarya sis wa kelas VIII-A yang diantaranya terdiri dari unsur pointilis, bentuk, ruang, gelap-terang, kemiripan bentuk, tekstur. Karya yang diteltiberjumlah sebanyak 5 karya dengan objek bunga anggrek, yang dinilai oleh guru senibudaya SMP Al- Fity an School Medan dan sebagai penilai II dan III Bapak/ Ibu Dosen Pendidikan Seni Rupa Universitas Negeri Medan. Tuti Hayati, S.Pd (penilai I), Drs. Nelson Tarigan, M.Si (penilai II), Drs. Bris man Silaban, M.Si. (penilai III).

Hasil penelitian tersebut dinilai dalam bentuk tabulasi data berupa instrumen penilaian lalu dianalisis dan dideskripsikan. Kemudian hasil penelitian dalam bentuk tabulasitersebut digabungkan dengan jumlah rata-rata tiap unsur pointilis, bentuk, ruang, gelapterang, kemiripan bentuk dan tekstur. Pada karya gambar bungaanggrek karya siswa kelas VIII-A SMP Al-fityan School Medan menunjukkan hasil karya tersebut termasuk dalam kategori baik.

\section{Pembahasan}

1).Karya Nazla Tobing

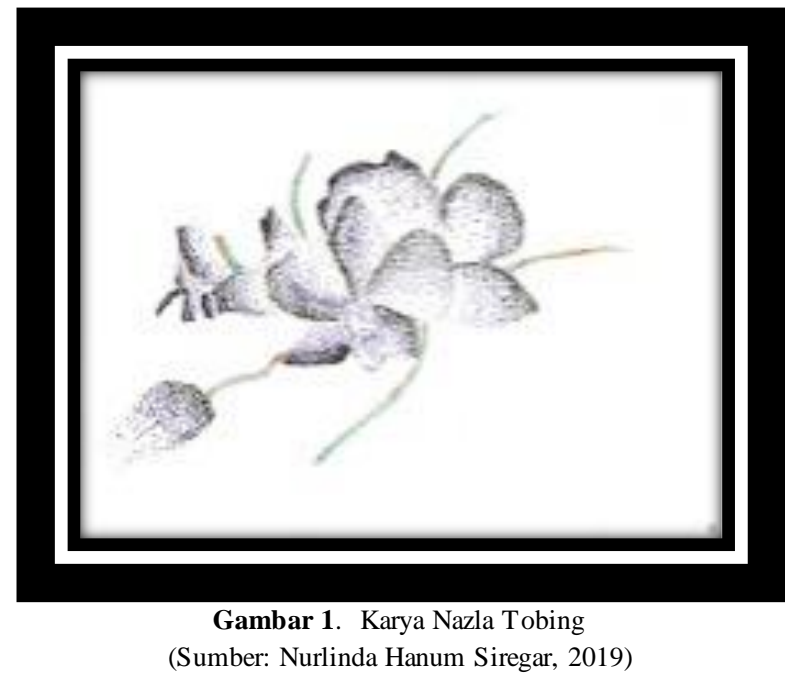

Berdasarkan analis is data yang telah dipaparkan di atas, maka dapat ditarik kesimpulan interpretasi data atau penafsiran data yang diperoleh pada karya gambar 1 mendapat kategori Baik (B) pada indikator pointilis, betuk, ruang, gelap-terang, kemiripan bentuk dan tekstur, dengan demikian keunggulan pada karya 
1 terletak pada unsur gelap-terang dan kemiripan bentuk, keunggulan tersebut terlihat dari gelap-terang sehing ga menimbulkan kemiripan bentuk. Kemudian kekurangan terletak pada unsur pointilis, kekurangannyaterlihat kurang rapat, sehingga kurang menghasilkan bentuk yang sangat baik.

\section{2).Syalsa Putri}

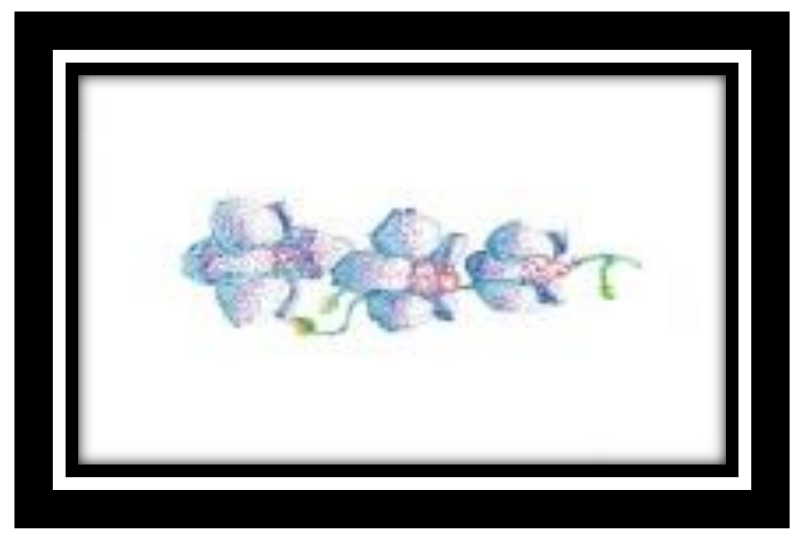

Gambar 2. Syalsa Putri

(Sumber: Nurlinda Hanum Siregar, 2019)

Berdasarkan analisis data yang telah dipaparkan di atas, maka dapat ditarik kesimpulan interpretasi data atau penafsiran data yang diperoleh pada karya gambar 3 mendapat kategori sangat Baik (A) pada indikator pointilis, betuk,ruang, gelap - terang, kemiripan bentuk dan tekstur, dengan demikian keunggulan pada karya 3 terletak pada unsur pointilis, bentuk gelap-terang, kemiripan bentuk dan tekstur, keunggulan tersebut terlihat dari gelap - terang sehingga menimbulkan kemiripan bentuk. Sehingga menghasilkan bentuk yang sangat baik.

\section{3).Reva}

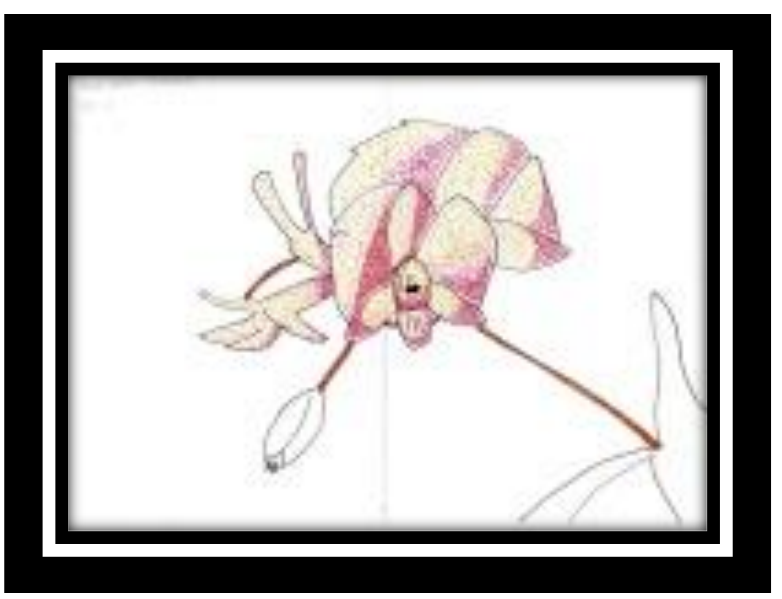

Gambar 3. Reva

(Sumber: Nurlinda Hanum Siregar, 2019)
Gorga : Jurnal Seni Rupa

Volume 09 Nomor 01 Januari-Juni 2020

p-ISSN: 2301-5942 | e-ISSN: 2580-2380

Berdasarkan analis is data yang telah dipaparkan di atas, maka dapat ditarik kesimpulan interpretasi data atau penafsiran data yang diperoleh pada karya gambar 7 mendapat kategori Baik (B) pada indikator gelap-terang dan pointilis. Kemudian kategori cukup baik pada indikator bentuk, ruang, gelap-terang, kemiripan bentuk dan tekstur, dengan demikian keung gulan pada karya gambar 7 terletak pada bagian gelap-terang y ang mana gelap-terang sudah diterapkan sehingga mulai menyerupai bentuk dengan adanya dimensi, dan kekurangan terletak pada unsur kemiripan bentuk tidak sesuai dengan objek sehingga tidak terlihat dengan baik.

\section{4).Risti}

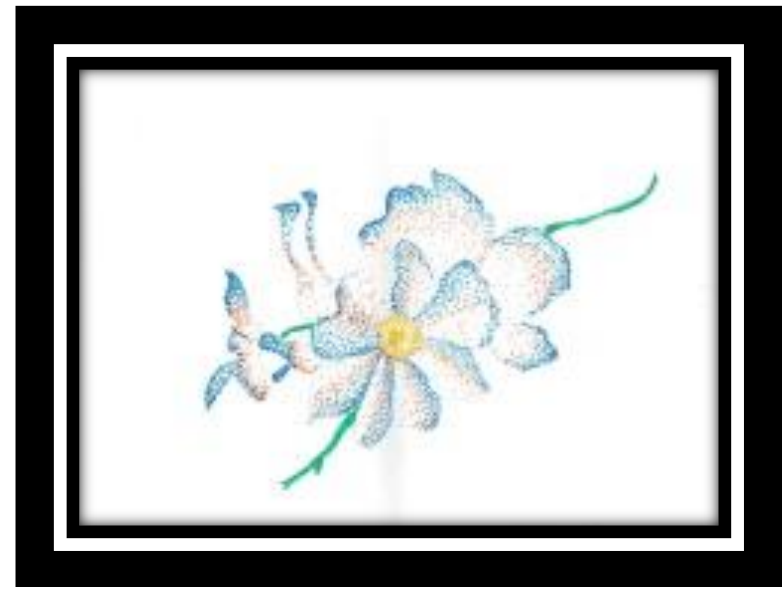

Gambar 4. Risti

(Sumber: Nurlinda Hanum Siregar, 2019)

Berdasarkan analis is data yang telah dipaparkan di atas, maka dapat ditarik kesimpulan interpretasi data atau penafsiran data yang diperoleh pada karya gambar 19 mendapat kategori sangat Baik (A) pada indikator pointilis, bentuk dan kemiripan bentuk, dan khusu snya nilai terendah berada pada indikator bentuk dengan nilai 88, dengan demikian keunggulan pada karya gambar 19 terletak pada pointilis bunga sudah sesuaidengan bunga anggrek sebenarnya, kemudian kekurangannya terletak pada unsur tekstur kurang kasar, dan penempatanya sudah tepat, sehingga dimensinya sudah sesuai pada bunga anggrek sebennarnya. 


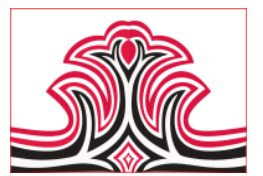

5).Deah Anggraini

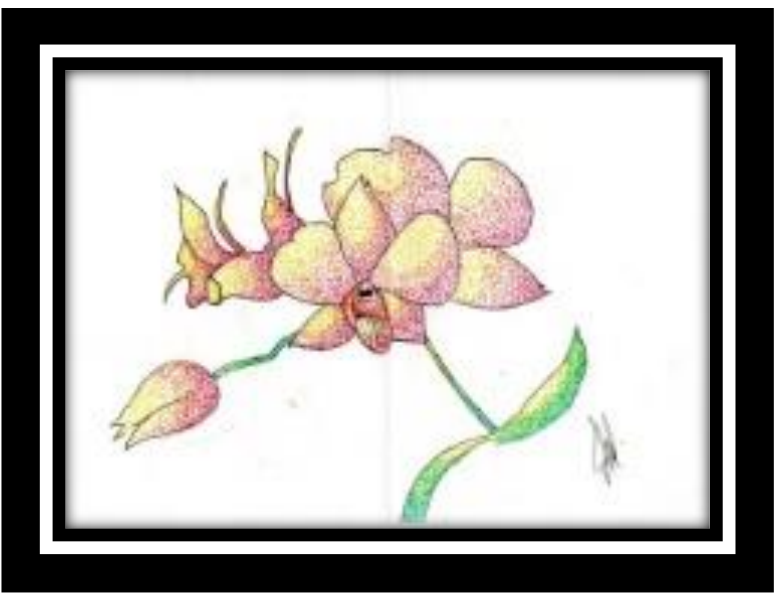

Gambar 5. Deah Anggraini

(Sumber: Nurlinda Hanum Siregar, 2019)

Berdasarkan analisis data yang telah dipaparkan di atas, maka dapat ditarik kesimpulan interpretasi data atau penafsiran data yang diperoleh pada karya gambar 21 mendapat kategori Sangat Baik (A) pada indikator pointilis, ruang, gelap-terang, kemiripan bentuk dan tekstur, dan khususnya nilai terendah berada pada indikator bentuk dengan nilai 89, dengan demikian keunggulan pada karya gambar 21 terletak pada kemiripan bentuk bunga sudah sesuai dengan bung a ang grek sebenarny a, kemudian kekurang annya terletak pada unsur bentuk yang terlihat sangat kaku pada bagian kelopaknya, dan penempatanya juga kurang sesuai, sehinggadimensinya jug a mulai sesuai pada bunga anggrek sebennarnya.

\section{KESIMPULAN DAN SARAN \\ 1.Kesimpulan}

Berdasa Berdasarkan rumusan masalah, landasan teori, pembahasan dan temuan hasil penelitian, maka dapat disimpulkan sebagai berikut :

1. Setelah diadakan pelatihan terhadap kemampuan siswa dalam menerapkan unsur unsur pointilis, bentuk, ruang, gelap-terang, kemiripan bentuk dan tekstur pada karya gambar bunga anggrek dengan teknik pointilis warna hasil karya siswa di kelas VIII-A SMP Al-fityan School Medan rata- rata mencapai (87) dan termasuk kategori Baik

2. Setelah diadakan pelatihan kepada siswa, hasil gambar bentuk bunga anggrek dengan teknik arsir pointilis warna karya sis wa kelas VIII SMP Al- Fityan School Medan. 6 unsur aspek penilaian yaitu pointilis, bentuk, ruang, gelapterang, kemiripan bentuk dan tekstur, memperoleh penilaian yang baik dari ketiga tim penilai. Berikut dariyang tertinggi sampai yang
Gorga : Jurnal Seni Rupa

Volume 09 Nomor 01 Januari-Juni 2020

p-ISSN: 2301-5942 | e-ISSN: 2580-2380

terendah yaitu aspek Gelap-terang dengan nilai rata-rata $=89$ (baik). Kemudian dari aspek bentuk dengan nilai rata-rata $=87$ (baik). Kemudian dari as pek ruang dengan nilai rata-rata $=86$ (baik). Kemudian dari aspek pointilis dengan nilai rata-rata $=88$ (baik). Kemudian dari aspek tekstur dengan nilai rata-rata $=87$ (baik). Kemudian dari aspek kemiripan bentuk dengan nilai rata-rata $=88$ (baik). Kemudian dari aspek ruang dengan nilai rata-rata $=86$ (baik) yang paling terendah.

\section{Saran}

Berdasarkan hasil penilaian, analisis dan simpulan penelitian, maka penelitian menyarankan.

1. Guru menjelaskan hal-hal konseptual yang berkaitan dengan pembuatan karya gambar bunga anggrek dengan teknik pointilis berwarna sehingga menghasilkan karya yang memiliki kualitas yang baik untuk kedepannya.

2. Siswa harus berlatih lebih sering lagi untuk membuat tarikan garis yang lebih luas, berlatih mengars ir objek gambar dengan baik ag ar gambar tersebut terlihat gelap terangnya.

3. Bagi penelitilain yang selanjutnya ingin meneliti tentang meng gambar bentuk supaya memperluas dan mengembangkan teknik-teknik dan objek yang menarik.

\section{DAFTAR RUJUKAN}

Furchan, Arief, (2007), Pengantar Penelitian Dalam Pendidikan. Yogyakarta:

PUSTAKABELAJAR

Harahap, M. H., Fais al, F., Hasibuan, N. I.,

Nugrahaningsih, R. H. D., \& Azis, A. C. K.

(2017). PENGEMBANGAN PROGRAM

LITERASI SEKOLAH UNTUK

MENINGKATKAN KUALITAS

PENDIDIKAN DASAR TINGKAT

SEKOLAH MENENGAH PERTAMA

NEGERI DI KOTA MEDAN. Jurnal

Pembangunan Perkotaan, 5(2), 115-128.

Nugroho, Eko, (2008), Pengenalan Teori Warna.

Yogyakarta:C.V AndiOffset.

Mesra, (2014), Gambar Bentuk., Medan: Unimed

Press.

Simatupang, Hareanto,(2013), ModulMenggambar Bentuk; Medan: UNIMED.

Sugiyono, (2016), Metode Penelitian Kuantitatif, Kualitatif \& $R$ dan $D$. Bandung: Alfabeta.

Swasty, Wirania , (2017), Serba Serbi Warna

Penerapan Pada Desain,Bandung: PT

Remaja Rosdakarya 
Tjitrosoepomo, Gembong, (2001), Morfologi

Tumbuhan, Yogyakarta: Gadja Mada

University Press.

Sumardi, Is sirep, (1993), Struktur Dan Pengembangan

Tumbuhan, Yogyakarta: Universitas Gaja

Mada. 